\title{
The Effect of Entrepreneurship Education on Graduate Students' Entrepreneurial Alertness and the Mediating Role of Entrepreneurial Mindset
}

\begin{abstract}
Purpose

This study investigates the effect of entrepreneurship education in terms of the development of entrepreneurial knowledge and skills, on graduate students' entrepreneurial alertness and the mediating role of the entrepreneurial mindset.

\section{Design/methodology/approach}

The study collected data using questionnaires from graduate students at an Iranian university who had engaged with entrepreneurship education. The questionnaires collected data on the respondents' demographics and adopted previously validated measures to measure entrepreneurship education, entrepreneurial alertness, and entrepreneurial mindset. Statistical techniques were applied to test validity, and structural equation modeling was undertaken to test the hypotheses.
\end{abstract}

\section{Findings}

The findings demonstrated that entrepreneurship education has a positive and significant effect on entrepreneurial alertness and entrepreneurial mindset. In addition, entrepreneurial mindset was found to have a positive and significant role in mediating the relationship between entrepreneurship education and entrepreneurial alertness. This finding highlights the importance of educators seeking to build an entrepreneurial mindset within entrepreneurship education, in addition to developing students' entrepreneurial alertness by focusing on opportunity identification and recognition.

\section{Originality/value}

The study addresses a gap in the literature as to the relationship between entrepreneurship education, entrepreneurial alertness, and the entrepreneurial mindset, and furthers the understanding of the impact of entrepreneurship education. The results inform educational practice, as ensuring students recognize entrepreneurial opportunities is an important element of venture creation. 
Saadat, S., Aliakbari, A., Alizadeh Majd, A. \& Bell, R. (2021) The effect of entrepreneurship education on graduate students' entrepreneurial alertness and the mediating role of entrepreneurial mindset, Education + Training. doi: 10.1108/ET-06-2021-0231

\section{Keywords}

Entrepreneurship Education, Entrepreneurial Alertness, Entrepreneurial Mindset, Opportunity Recognition, Iran 
Saadat, S., Aliakbari, A., Alizadeh Majd, A. \& Bell, R. (2021) The effect of entrepreneurship education on graduate students' entrepreneurial alertness and the mediating role of entrepreneurial mindset, Education + Training. doi: 10.1108/ET-06-2021-0231

\section{Introduction}

Entrepreneurship denotes recognizing and taking advantage of opportunities previously unrecognized as opportunities (Fuduric, 2008). Similarly, Kelley et al. (2012) argue that the practical process of launching a new business begins with utilizing an opportunity. However, despite Iran's intention to support the development of small and medium enterprises (SMEs), there are several factors limiting the successful achievement of this goal, including education, demographic characteristics, technology, and economic and policy issues (Ahadi and Kasraie, 2020). This has led to an issue with national production, which is currently at a low level with many companies potentially facing closure, through low productivity, lack of demand and weak positioning in global markets (Daneshjoovash and Hosseini, 2019). The economic crisis and sanctions have led the government to favor entrepreneurship, but in practice, official assistance for key infrastructures such as making it easier to start a new firm and giving lowinterest loans appears to be minimal. As a result, the percentage of adults planning to establish a business in the next three years in Iran has dropped from 38\% in 2019 to $24 \%$ in 2020 (GEM, 2020).

Entrepreneurship education has a prominent role to play in increasing economic growth, and entrepreneurship graduates are the main players in the dynamism and flexibility of business environments (O' Connor, 2013). This belief has led to the development and inclusion of entrepreneurship education at many universities in Iran, to encourage and develop students' and graduates' propensity to entrepreneurship (Karimi et al., 2010). This has led to entrepreneurship education being on the agendas of Iranian universities (Dehghanpour Farashah, 2013). However, entrepreneurship education in Iranian higher education is at a relatively low level when contrasted to other countries such as the US and Europe (Farsi et al., 2014; Daneshjoovash and Hosseini, 2019) and it appears that the entrepreneurship education offered is not always sufficient to increase entrepreneurial activity (Karimi et al., 2010).

The concept of entrepreneurial alertness has become a key construct in entrepreneurial research (Tang et al., 2012) and is one of the characteristics of opportunistic entrepreneurs, which can be considered as a fundamental concept in entrepreneurship (Gaglio and Katz, 2001; Minniti, 2004). Kirzner (1973) was the first person to use the word alertness to identify entrepreneurial opportunities and he defined entrepreneurial alertness as a factor to clarify superior insight. Ardichvili et al. (2003) maintain that entrepreneurial alertness is one of the most important factors in identifying entrepreneurial opportunities. Ardichevili and Cardozo (2000) have 
Saadat, S., Aliakbari, A., Alizadeh Majd, A. \& Bell, R. (2021) The effect of entrepreneurship education on graduate students' entrepreneurial alertness and the mediating role of entrepreneurial mindset, Education + Training. doi: 10.1108/ET-06-2021-0231

considered previous knowledge as one of the effective factors in identifying opportunities. Corbett (2007) believes that the study of cognitive mechanisms, such as learning and education and their interactions with the individual's existing knowledge, constitute one of the most important pieces of the opportunity identification puzzle. Entrepreneurship education increases the performance level of dimensions such as attitude, knowledge, and skills, and therefore entrepreneurship is chosen as a career path (Kozlinska, 2012).

Many researchers agree that alertness includes an entrepreneurial mindset based on several capacities and processes such as previous knowledge, pattern recognition skills, and information processing (Cui et al., 2021). The notion of mindset originates from the cognitive psychology field. Mindsets are not inherent and can be influenced and taught by a person's previous knowledge and through interaction with the current environment (Mathisen and Arnulf, 2014). Entrepreneurial mindset is focused attention as a deep cognitive phenomenon that reflects flexible cognitive structures (Krueger, 2015). An entrepreneurial mindset enables individuals to think and act entrepreneurially as it underlies successful future strategies (Covin and Slevin, 2017).

This research seeks to determine what effect entrepreneurship education has on entrepreneurial alertness in graduate students and how entrepreneurial mindset mediates this relationship. Such an approach addresses a gap in the literature as to the relationship between entrepreneurship education and entrepreneurial alertness and meets calls to further our understanding of the impact of entrepreneurship education (Nabi et al., 2017). Understanding the impact of entrepreneurship education on entrepreneurial alertness can help to develop educational practice, ensuring that students completing entrepreneurship programs can recognize entrepreneurial opportunities, which is important in supporting new venture creation (Bueckmann-Diegoli et al., 2020). This in turn can help to inform entrepreneurship education practice and policy in Iran to support nascent entrepreneurs to successfully identify entrepreneurial opportunities. Additionally, this research addresses the paucity of studies that explore how entrepreneurship education influences entrepreneurial mindset (Nabi et al. 2017; Yatu et al. 2018). Connecting the concepts of entrepreneurship education, entrepreneurial mindset and entrepreneurial alertness contributes to furthering the understanding of the impact of entrepreneurship education. Exploring the mediating influence of entrepreneurial mindset provides a novel angle, as educational and pedagogical research has employed entrepreneurial mindset almost exclusively as a dependent variable (Daspit et al., 2021). 
Saadat, S., Aliakbari, A., Alizadeh Majd, A. \& Bell, R. (2021) The effect of entrepreneurship education on graduate students' entrepreneurial alertness and the mediating role of entrepreneurial mindset, Education + Training. doi: 10.1108/ET-06-2021-0231

This study is structured as follows: First, a research literature review is provided, followed by the proposed hypotheses and a conceptual model of the research. Secondly, the methodology is described, including the sample and measures. Thirdly, the findings are presented, followed by a discussion section. Finally, a conclusion is provided including a discussion of the limitations of the research and future research directions.

\section{Literature review}

The literature review discusses the existing literature around the themes of entrepreneurship education, entrepreneurial mindset, and entrepreneurial alertness to link the concepts and build the hypotheses underpinning the research.

\section{Entrepreneurship education}

Entrepreneurship can be considered to be a key contributor to both economic growth and development (Singer et al., 2015) and is widely regarded as a critical economic development strategy in terms of wealth and job creation (Nyadu-Addo and Mensah, 2018). Entrepreneurial skills are increasingly considered as an essential element of entrepreneurial economics (Muñoz et al., 2011) and entrepreneurial characteristics can support graduates to both start new ventures and gain graduate level jobs (Bell, 2016). It is for such reasons that entrepreneurship education is increasingly being seen not only as the preserve of the selected few with entrepreneurial ideas, but relevant to a wider range of students in higher education (Bell and Bell, 2016; O’Brien et al., 2019).

Previously, a common assumption was that entrepreneurs were innately entrepreneurial and characterized by such traits as innovation, creativity, high intelligence, positivity, and a risktaking attitude, as well as higher perception skills (Kuratko, 2005). In the meantime, the role of education and developing entrepreneurship was ignored. Therefore, entrepreneurship education was focused on individuals who demonstrated these entrepreneurial traits (Hodgetts and Kuratko, 1989). However, entrepreneurship education has been accepted by many authors as an effective tool for cultivating entrepreneurship (Dutta et al., 2011). The literature highlights that engagement with business simulations and entrepreneurial scenarios (Avramenko, 2012; Solomon, 2008), presenting and pitching entrepreneurial ideas (Bliemel, 
Saadat, S., Aliakbari, A., Alizadeh Majd, A. \& Bell, R. (2021) The effect of entrepreneurship education on graduate students' entrepreneurial alertness and the mediating role of entrepreneurial mindset, Education + Training. doi: 10.1108/ET-06-2021-0231

2013), studying entrepreneurship case studies (Chang et al., 2014), and learning from role models and guest speakers can all have a positive impact.

Some experts believe that modern universities should take an entrepreneurial approach to become a place where entrepreneurship education plays the main role (Gibb, 2007; Abreu et al., 2016). Olutuase et al. (2018) highlighted the value of developing an entrepreneurial ecosystem tailored to the needs of the students, to complement entrepreneurship education. According to Solesvik et al. (2013, p.748), “Universities provide entrepreneurship-specific education (ESE) to equip students with the entrepreneurial alertness and risk-taking assets required to pursue entrepreneurial careers'.

Entrepreneurship education is widely supported to produce opportunities for developing young emerging entrepreneurs (Sierlkhatim and Gangi, 2015). Achieving the desired results of entrepreneurial activities comes from the entrepreneurial mindset which is rooted in cognitive adjustment (Krauss et al., 2005; Shepherd et al., 2010). Entrepreneurial mindset can be strengthened through education and can be considered as a mental habit that needs to be learned to take shape (Schmidt and Ford, 2003).

Bell and Bell (2020) posit that effective entrepreneurship education should provide students with the theoretical grounding and knowledge about entrepreneurship and should enable students to engage with practical experiences where this knowledge can be critically applied to develop practical entrepreneurial skills. Engaging with practical projects can lead students to develop their self-efficacy in accordance with the tangible achievements from this type of practical activity (Nowinsky et al., 2019). Practical entrepreneurship education activities focusing on creating value, can support students in identifying entrepreneurial opportunities (Lackéus, 2020). Entrepreneurship education has a positive effect on the development of students' creativity in solving problems, communication skills, and opportunity identification (Karlsson and Moberg, 2013; Muñoz et al., 2020). It is clear that there is much evidence that entrepreneurship education has a positive impact on students, and the capacity of students to recognize opportunities has been observed in studies (Muñoz et al., 2011). Therefore, the following two hypotheses are proposed:

Hypothesis 1: Entrepreneurship education has a positive effect on entrepreneurial alertness.

Hypothesis 2: Entrepreneurship education has a positive effect on entrepreneurial mindset. 
Saadat, S., Aliakbari, A., Alizadeh Majd, A. \& Bell, R. (2021) The effect of entrepreneurship education on graduate students' entrepreneurial alertness and the mediating role of entrepreneurial mindset, Education + Training. doi: 10.1108/ET-06-2021-0231

\section{Entrepreneurial mindset}

McGrath and MacMillan (2000) initially defined entrepreneurial mindset as the ability to quickly feel, act, and move under high uncertain circumstances. Shepherd et al. (2010) defined entrepreneurial mindset as the capacity to respond and make a decision concerning uncertainty regarding an opportunity. McMullen and Kier (2016), stressed that the entrepreneurial mindset is the ability to identify and utilize opportunities without regard for the resources at the entrepreneur's disposal, implying that entrepreneurial activity may involve facing risks to some degree. Other definitions of entrepreneurial mindset differ in the literature, but what they have in common is that the entrepreneurial mindset is a way of thinking or the ability to utilize opportunities under uncertain conditions (Cui et al., 2021).

According to McMullen and Kier (2016), inspired by Kirzner's theory of entrepreneurial alertness $(1973 ; 1997)$, the entrepreneurial mindset rests on an opportunity-based conception of entrepreneurship in which entrepreneurs are individuals who identify and exploit opportunities, defined as environmental contingencies that allow the replacement of what have become sub-optimal goals with new superior means-ends frameworks. Thus, managers with an entrepreneurial mindset may not feel compelled to plan because the opportunity seeking behavior engendered by the entrepreneurial mindset prepares them to notice and seize opportunities revealed by the dissipation of environmental uncertainty.

Outsios and Kittler (2018) identified an individual's educational experiences as one factor which influences a person's entrepreneurial mindset. Cui et al. (2021) studied further the link between these concepts and found that entrepreneurship education had a positive impact on entrepreneurial mindset and on stimulating students' entrepreneurial inspirations. Pirhadi et al. (2021) proposed that developing entrepreneurial skills and character in students can help to effectively develop the ability to assess desirability and feasibility of entrepreneurial opportunities, thus developing their entrepreneurial alertness. This work builds on this proposition to propose that:

Hypothesis 3: Entrepreneurial mindset positively affects entrepreneurial alertness.

\section{Entrepreneurial alertness}

Kirzner (1979) was one of the first scholars to use the word entrepreneurial alertness to analyze and explain the identification of entrepreneurial opportunities. Kirzner points out that 
Saadat, S., Aliakbari, A., Alizadeh Majd, A. \& Bell, R. (2021) The effect of entrepreneurship education on graduate students' entrepreneurial alertness and the mediating role of entrepreneurial mindset, Education + Training. doi: 10.1108/ET-06-2021-0231

entrepreneurs, both in the present and in the foreseeable future, need to be aware of discovering opportunities (Kirzner, 2009). Prior to that, he argued that entrepreneurial alertness was referring to focusing attention to ignored opportunities even without searching for them (Kirzner, 1979). He called this perception of alertness a passion for formulating a picture of the future (Kirzner, 1986). According to his findings, alertness has the potential to add value to the business, because it helps entrepreneurs to be aware of changes, opportunities, and unseen situations (Kirzner, 1999). He examines the ability to recognize and be aware of situations in terms of paying attention to things we have never even suspected existed (Kirzner, 2008). It has been found that entrepreneurial alertness, can mediate the relationship between entrepreneurial training and the entrepreneurial mindset of employees (Naeiji and Ebrahimi, 2017).

The entrepreneurial opportunity acquisition process by alerted individuals is a conscious and meticulous process that involves recognizing and utilizing an opportunity (Lumpkin and Liechtenstein, 2005). Entrepreneurial alertness serves as a cognitive resource an entrepreneur makes use of and is more capable of identifying business opportunities in the market than others (Helfat and Peterag, 2015). By studying entrepreneurial alertness and its impact on organizational entrepreneurship, Lee et al. (2016) demonstrated that entrepreneurial alertness can distinguish entrepreneurial organizational behavior, can speed up management team decisions and can improve the process of recognizing entrepreneurial opportunities.

Tang et al. (2012) view entrepreneurial alertness as one of the most critical factors for identifying entrepreneurial opportunities, investigating alertness from three perspectives: Alert scanning and search; alert association, and connection; evaluation, and judgment. In effect, they state that alertness is the ability to assemble random pieces of scattered information and combine it to analyze and achieve an entrepreneurial opportunity (Tang et al., 2012). By investigating pragmatism in entrepreneurial alertness, Neneh (2019) concluded that in the process of alertness, entrepreneurial creativity, pragmatism, and commitment are the features which play a key role. Daspit et al. (2021) suggest that entrepreneurial experience, including educational experience, develops entrepreneurial mindset through broadening perspective, thereby changing how a person recognizes and creates opportunities. This leads to the following hypothesis:

Hypothesis 4: Entrepreneurship education with the mediating role of entrepreneurial mindset influences entrepreneurial alertness. 
Saadat, S., Aliakbari, A., Alizadeh Majd, A. \& Bell, R. (2021) The effect of entrepreneurship education on graduate students' entrepreneurial alertness and the mediating role of entrepreneurial mindset, Education + Training. doi: 10.1108/ET-06-2021-0231

Based on the literature review, the conceptual model of the research is presented in figure 1.

Figure 1 Conceptual Research Model

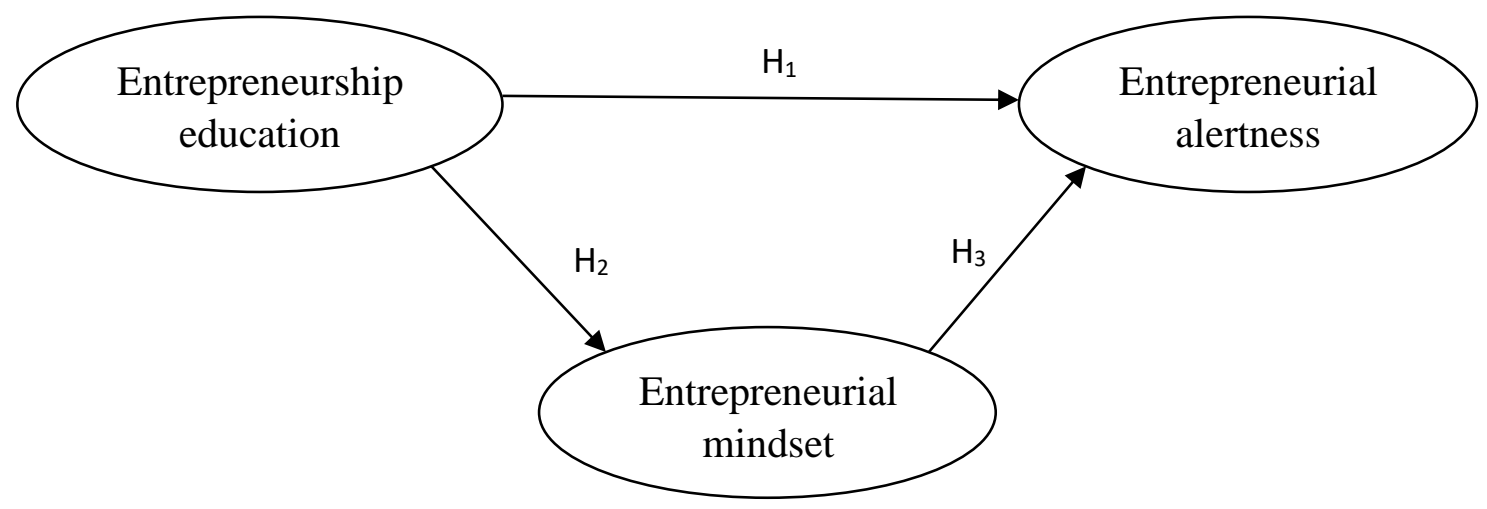

\section{Methodology}

The statistical population of the study consisted of graduate students majoring in business administration at the Islamic Azad University of Iran (South Tehran Branch), who had participated in an entrepreneurship course. The entrepreneurship course combined both the teaching of entrepreneurship theory and practical activities. It was designed to develop entrepreneurial knowledge, attitudes, and skills. The course involved a range of entrepreneurial activities which included the discussion of entrepreneurship, development of business ideas in the Iranian context, pitching and presenting ideas, the exploration and discussion of entrepreneurial case studies and role models, and the exploration of sales and marketing strategies. The questionnaires were distributed to all the 133 students enrolled on the entrepreneurship course. Of the 133 questionnaires distributed 127 were fully completed and returned. Any questionnaires that were answered and submitted in less than five minutes were eliminated. This action was undertaken to improve the reliability of the data included within the study. As a result, 91 questionnaires were selected to be utilized in the research. The questionnaire used to collect data from this study consisted of 49 items. The first part of the questionnaire included questions to collect the demographic information of the individual respondent, whilst the second part included questions on a 7-point Likert scale relating to the three concepts of entrepreneurship education, entrepreneurial alertness, and entrepreneurial mindset, being assessed in the hypotheses. The demographic characteristics of the studied sample indicate that $52.75 \%$ of the respondents were male and $47.25 \%$ were female. Further details of the sample demographic are summarized in table 1. 
Saadat, S., Aliakbari, A., Alizadeh Majd, A. \& Bell, R. (2021) The effect of entrepreneurship education on graduate students' entrepreneurial alertness and the mediating role of entrepreneurial mindset, Education + Training. doi: 10.1108/ET-06-2021-0231

Table 1 Sample Demographics

\begin{tabular}{|c|c|c|c|}
\hline $\begin{array}{l}\text { Variables } \\
(\%)\end{array}$ & & Frequency & Percent \\
\hline \multirow[t]{2}{*}{ Gender } & Male & 48 & $52.75 \%$ \\
\hline & Female & 43 & $47.25 \%$ \\
\hline \multicolumn{4}{|l|}{ Age } \\
\hline & $21-25$ & 10 & $11.00 \%$ \\
\hline & $26-30$ & 27 & $29.67 \%$ \\
\hline & $31-35$ & 26 & $28.57 \%$ \\
\hline & $36-40$ & 14 & $15.38 \%$ \\
\hline & $41-45$ & 10 & $11.00 \%$ \\
\hline & $46-50$ & 3 & $3.29 \%$ \\
\hline & $>50$ & 1 & $1.09 \%$ \\
\hline \multirow[t]{6}{*}{ Job Experience } & $<5$ & 25 & $27.47 \%$ \\
\hline & $5-10$ & 28 & $30.77 \%$ \\
\hline & $11-15$ & 20 & $21.98 \%$ \\
\hline & $16-20$ & 8 & $8.79 \%$ \\
\hline & $21-25$ & 8 & $8.79 \%$ \\
\hline & $>25$ & 2 & $2.20 \%$ \\
\hline
\end{tabular}

$\mathrm{N}=91$

The variables of entrepreneurship education, entrepreneurial alertness, and entrepreneurial mindset were all measured by adopting previously validated scales. Entrepreneurship education was measured by adopting Afrianty's (2020) ten item measurement instrument, which assesses the development of entrepreneurial knowledge and skills within entrepreneurship education. To measure the entrepreneurial alertness variable the 13 scales developed and validated by Tang et al. (2012) were adopted, whilst entrepreneurial mindset was measured using the constructs and scales employed by Cui et al. (2021). The scales were translated into Persian and checked by native speakers through a process of backtranslation to ensure conceptual equivalency (Bhalla and Lin, 1987). 
Saadat, S., Aliakbari, A., Alizadeh Majd, A. \& Bell, R. (2021) The effect of entrepreneurship education on graduate students' entrepreneurial alertness and the mediating role of entrepreneurial mindset, Education + Training. doi: 10.1108/ET-06-2021-0231

Although the scales had previously been validated, preliminary and validity testing was undertaken to confirm the validity of the scales in the Iranian context. As each of the variables considered within the research are psychological constructs, the data collected from the questionnaires was subjected to factor analysis to check the factor loadings of the individual items. Based on recommendations within the literature, items which displayed factor loadings below 0.4 were removed to support a clean factor structure (Henseler et al. 2009; Hulland, 1999). This led to 28 items being eliminated, shown in appendix 1, whilst the items included, and their factor loadings, are presented in table 2. A t-test was conducted to determine whether the entrepreneurship education variable score was different for men and women in the sample. The test determined there was not a statistical difference between the entrepreneurship education score of men $($ mean $=4.50)$ and women $($ mean $=4.82)$.

Table 2 Item Loadings

Variables

Item Description

Factor

Loading

Entrepreneurship

Education
I became more conscious of the entrepreneurial environment after taking the entrepreneurship course

For me the entrepreneurship course adds to my knowledge of business

The entrepreneurship course offered and gave me a better understanding of the qualities that must be possessed to become an entrepreneur

The theory that is given supports me to create a new business

The entrepreneurship course material taught contains the latest developments in business

The learning method used is more interactive, making it easier for me to understand business

I became more familiar with the business environment because of projects/assignments given by lecturers

Entrepreneurial I browse the Internet every day

Alertness
I am an avid information seeker

I am always actively looking for new information 
Saadat, S., Aliakbari, A., Alizadeh Majd, A. \& Bell, R. (2021) The effect of entrepreneurship education on graduate students' entrepreneurial alertness and the mediating role of entrepreneurial mindset, Education + Training. doi: 10.1108/ET-06-2021-0231

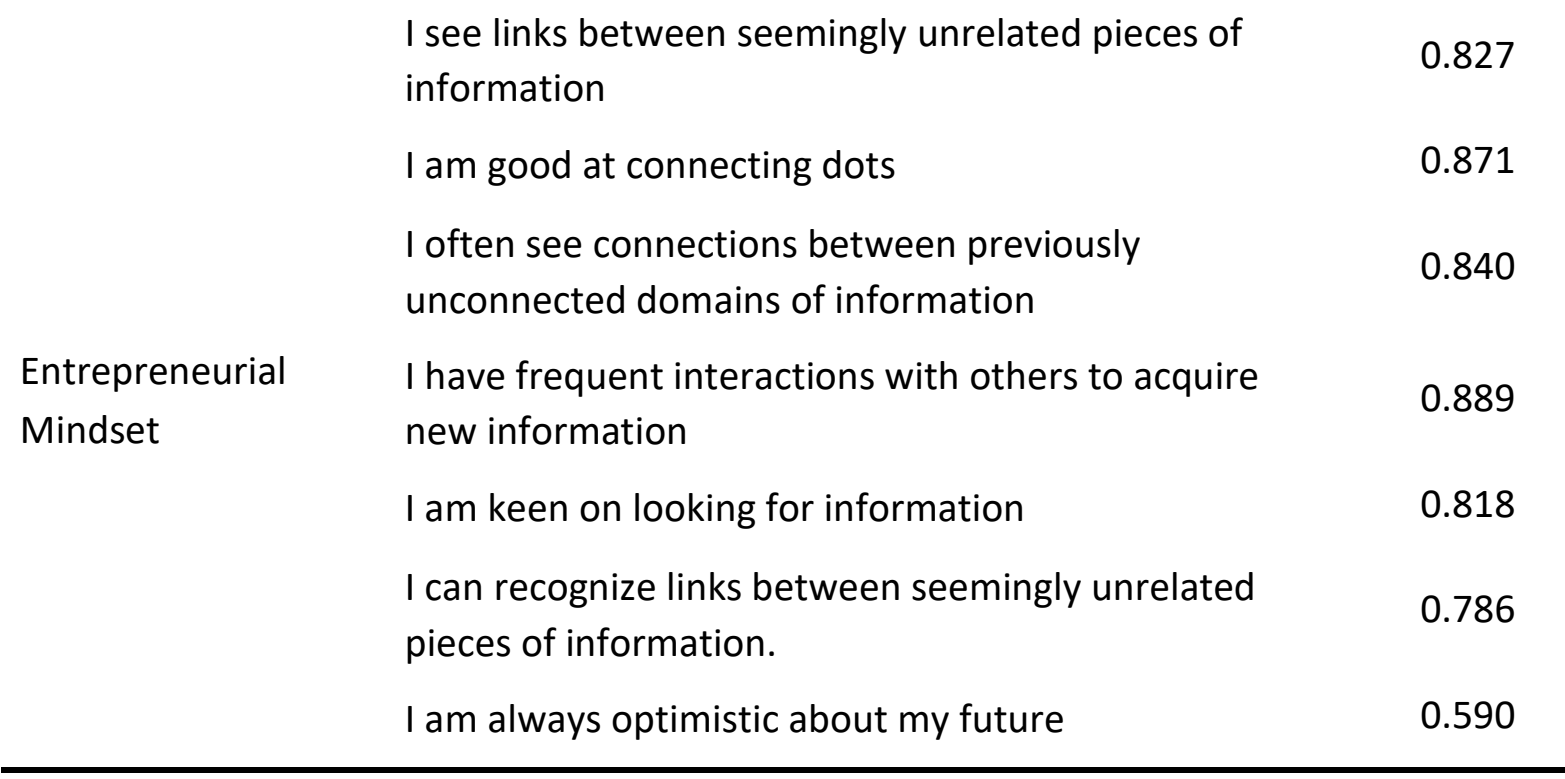

Although the scales had previously been validated this process helped to ensure construct validity in the Iranian context. Convergent validity was demonstrated through the average variance extracted (AVE) being above 0.5 for each of the variables (Cool et al., 1989). The AVE scores for each of the variables are presented in table 3. Finally, the criterion for discriminant validity was assessed through comparing the AVE square root of each variable with the amount of correlation among the constructs in table 4. It was identified that the AVE square root of each variable was higher than the correlation coefficient of the variable which provides acceptable evidence of divergent validity (Fornell and Larcker, 1981).

Table 3 Convergent Validity of Research Variables

Variable AVE

Entrepreneurship education

Entrepreneurial alertness

0.746

Entrepreneurial mindset

0.606 
Saadat, S., Aliakbari, A., Alizadeh Majd, A. \& Bell, R. (2021) The effect of entrepreneurship education on graduate students' entrepreneurial alertness and the mediating role of entrepreneurial mindset, Education + Training. doi: 10.1108/ET-06-2021-0231

Table 4 Results of Divergent Validity of Variables

\begin{tabular}{lccc}
\hline Variable & EE & EA & EM \\
\hline Entrepreneurship education & & & \\
Entrepreneurial alertness & 0.819 & - & - \\
Entrepreneurial mindset & 0.770 & 0.864 & - \\
\hline
\end{tabular}

The reliability of the data was assessed using Composite Reliability and Cronbach Alpha scores and is presented in table 5. Both the Composite Reliability and Cronbach Alpha scores for each variable provided robust evidence for internal consistency and reliability of the measures, by exhibiting scores above 0.8 and 0.7 respectively (Bland and Altman, 1997; Netemeyer et al., 2003).

Table 5 Composite Reliability and Cronbach Alpha Scores

\begin{tabular}{lcc}
\hline \multicolumn{1}{c}{ Variable } & Composite Reliability & Cronbach's Alpha \\
\hline & & \\
Entrepreneurship education & 0.934 & 0.918 \\
Entrepreneurial alertness & 0.946 & 0.931 \\
Entrepreneurial mindset & 0.857 & 0.778 \\
\hline
\end{tabular}

Before moving onto the hypotheses testing, a Kolmogorov-Smirnov test was used to analyze the data to examine the normalcy of data distribution, and the results are shown in table 6 . Because the significance level of the test is less than 0.05 , the assumption of data normalcy is not confirmed. Therefore, to test the research hypotheses, structural equation modeling was used using PLS software. 
Saadat, S., Aliakbari, A., Alizadeh Majd, A. \& Bell, R. (2021) The effect of entrepreneurship education on graduate students' entrepreneurial alertness and the mediating role of entrepreneurial mindset, Education + Training. doi: 10.1108/ET-06-2021-0231

Table 6 Kolmogorov-Smirnov Test Results

\begin{tabular}{ccccc}
\hline Variable & Average & Standard deviation & statistic test & significance level \\
\hline EE & 6.45 & 1.93 & 0.212 & 0.000 \\
EA & 6.52 & 1.75 & 0.189 & 0.000 \\
EM & 6.60 & 2.16 & 0.215 & 0.000 \\
\hline
\end{tabular}

\section{Findings}

The data was analyzed using SPSS software version 26 and Smart PLS version 3.2.8 to conduct structural equation modeling to test the hypotheses proposed. The first criterion for examining the fit of a structural model is the $\mathrm{R}^{2}$ figure which is related to the endogenous (dependent) variables within the model. The $\mathrm{R}^{2}$ figure is a measure which indicates the effect of an exogenous variable on an endogenous variable. The $\mathrm{R}^{2}$ figure for the model structure demonstrated strong and good criterion fit for the structural model (entrepreneurial alertness $\mathrm{R}^{2}=0.634$ and entrepreneurial mindset $\mathrm{R}^{2}=0.247$ ). The $\mathrm{Q}^{2}$ figure of the endogenous variables identified that the predictive power of the model was strong (entrepreneurial alertness 0.44) and average (entrepreneurial mindset 0.13 ). To estimate the overall fit, the goodness of fit (GOF) criterion was calculated which explains the average of the common values of latent variables within the research. The overall GOF figure for the model was 0.54, which demonstrated a strong and appropriate fit of the overall model. Table 7 summarizes the conceptual model fit, whilst the results of the model in the form of the structural equations are summarized in figures 2 and 3. 
Saadat, S., Aliakbari, A., Alizadeh Majd, A. \& Bell, R. (2021) The effect of entrepreneurship education on graduate students' entrepreneurial alertness and the mediating role of entrepreneurial mindset, Education + Training. doi: 10.1108/ET-06-2021-0231

Table 7 Conceptual Model Fit

\begin{tabular}{lcc}
\hline \multicolumn{1}{c}{ Variable } & $\mathbf{R}^{\mathbf{2}}$ & Communality (AVE) \\
\hline Entrepreneurship education & - & 0.672 \\
Entrepreneurial alertness & 0.634 & 0.746 \\
Entrepreneurial mindset & 0.247 & 0.606 \\
Mean & 0.440 & 0.674 \\
& & \\
Gof & \multicolumn{2}{c}{0.544} \\
\hline
\end{tabular}

Figure 2 Path Coefficients

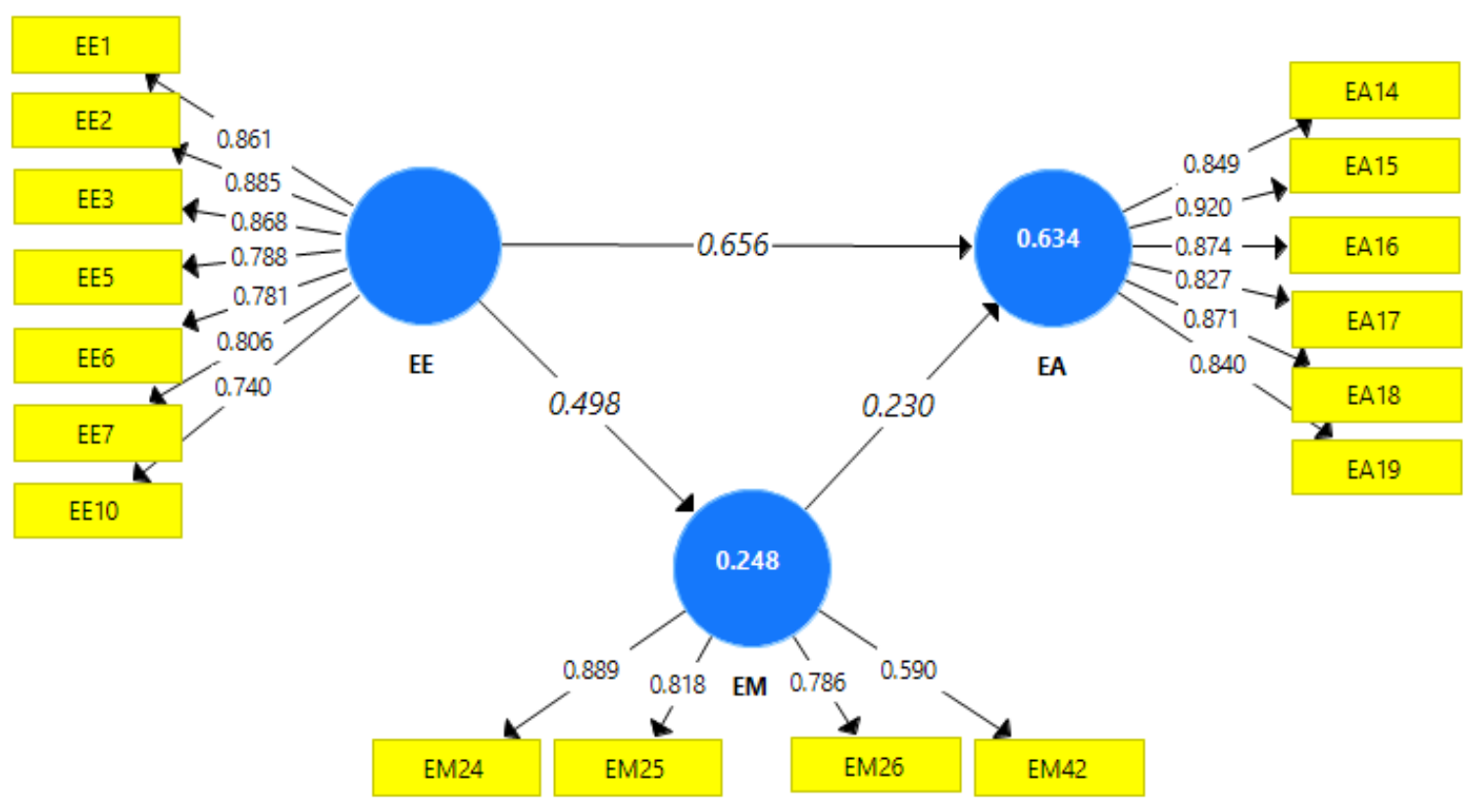


Saadat, S., Aliakbari, A., Alizadeh Majd, A. \& Bell, R. (2021) The effect of entrepreneurship education on graduate students' entrepreneurial alertness and the mediating role of entrepreneurial mindset, Education + Training. doi: 10.1108/ET-06-2021-0231

Figure 3 T-Statistics

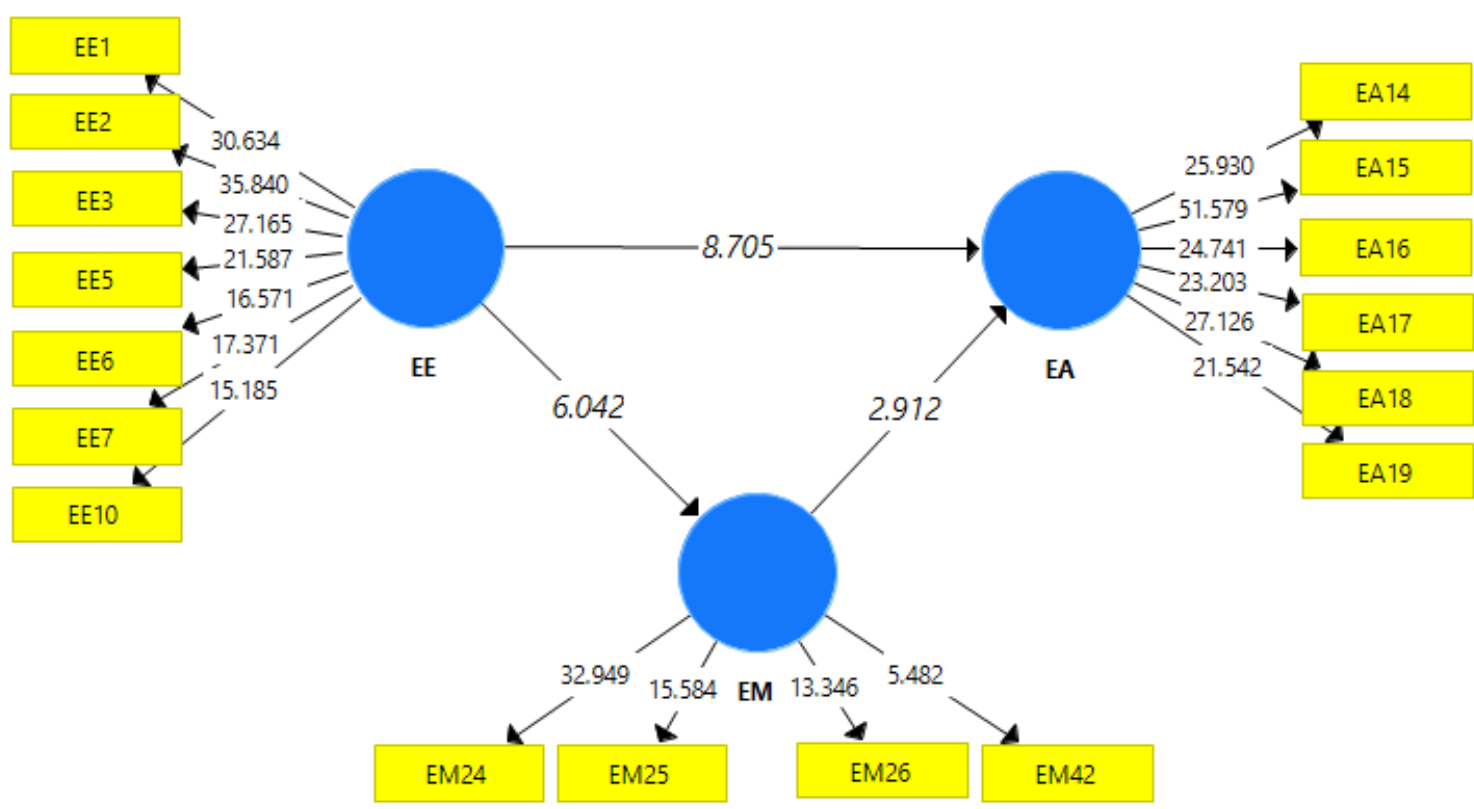

In the research framework, several criteria were used, the first and most basic of which were the $\mathrm{Z}$ significance coefficients or t-values. These coefficients must be greater than 1.96 to confirm the significance of the path and the appropriateness of the structural model as well as the significance of the relationship between each question and the relevant variable at the $95 \%$ confidence level. The results demonstrate a positive and significant relationship between entrepreneurship education and entrepreneurial alertness (H1), entrepreneurship education and entrepreneurial mindset (H2), and entrepreneurial mindset and entrepreneurial alertness (H3). In addition, the causal coefficients of the paths among the three constructs within the study demonstrate that entrepreneurial mindset plays a positive and significant mediating role in the relationship between entrepreneurship education and entrepreneurial alertness $(\mathrm{H} 4)$; as a result, entrepreneurial mindset has complementary partial mediation between entrepreneurship education and entrepreneurial alertness. According to the research model tested by structural equation modeling the answer to each research hypothesis is presented in table 8 . 
Saadat, S., Aliakbari, A., Alizadeh Majd, A. \& Bell, R. (2021) The effect of entrepreneurship education on graduate students' entrepreneurial alertness and the mediating role of entrepreneurial mindset, Education + Training. doi: 10.1108/ET-06-2021-0231

Table 8 Summary of Hypotheses Tests

\begin{tabular}{llllllll}
\hline Hypothesis & $\begin{array}{l}\text { Independent } \\
\text { Variable }\end{array}$ & Effect & $\begin{array}{l}\text { Dependent } \\
\text { Variable }\end{array}$ & $\begin{array}{l}\text { Path } \\
\text { coefficient }\end{array}$ & $\begin{array}{l}\text { T- } \\
\text { Statistic }\end{array}$ & $\begin{array}{l}\text { P- } \\
\text { Value }\end{array}$ & Result \\
\hline H1 & EE & Direct & EA & 0.656 & 8.705 & 0.00 & Approved \\
H2 & EE & Direct & EM & 0.498 & 6.042 & 0.00 & Approved \\
H3 & EM & Direct & EA & 0.230 & 2.912 & 0.00 & Approved \\
H4 & EE & EM & EA & 0.115 & 2.394 & 0.02 & Approved \\
& & & & & & \\
\hline
\end{tabular}

\section{Discussion and Implications}

This research was designed to investigate the effect of entrepreneurship education in terms of the development of entrepreneurial knowledge and skills, on graduate students' entrepreneurial alertness and the mediating role of the entrepreneurial mindset.

The first hypothesis of the research is based on the effect of entrepreneurship education on entrepreneurial alertness. To the best of our knowledge, the present research is the first to find that entrepreneurship education has a positive and significant direct effect on entrepreneurial alertness. This finding adds further emphasis to the considerable weight of findings which highlight the importance and value of entrepreneurship education in supporting entrepreneurship, as entrepreneurial alertness and opportunity recognition have been found to be part of entrepreneurship. This finding highlights the value of entrepreneurship education in the Iranian context, as it can support students' entrepreneurial alertness. The findings also build on the findings of Muñoz et al. (2011) and Karlsson and Moberg (2013), who found entrepreneurship education could develop students' creativity in solving problems, communication skills, and opportunity identification by identifying a link between entrepreneurship education and entrepreneurial alertness, which is built on these key entrepreneurial characteristics.

The second hypothesis of the research is based on the effect of entrepreneurship education on entrepreneurial mindset, and the findings indicate that entrepreneurship education has a positive and significant effect on entrepreneurial mindset. These results were consistent with the observations of Solesvik et al. (2013) and Cui et al. (2021) who confirmed the positive effect of entrepreneurship education on entrepreneurial mindset. Thus, the more effective the development of entrepreneurial knowledge and skills within entrepreneurship education, the more likely it is to increase entrepreneurial mindset and alertness. The measure used to assess 
Saadat, S., Aliakbari, A., Alizadeh Majd, A. \& Bell, R. (2021) The effect of entrepreneurship education on graduate students' entrepreneurial alertness and the mediating role of entrepreneurial mindset, Education + Training. doi: 10.1108/ET-06-2021-0231

entrepreneurship education was based on the development of both entrepreneurial knowledge and skills, and the findings highlight that the development of both areas is important in the development of entrepreneurial alertness and entrepreneurial mindset. This supports recent literature which highlights the value of developing both knowledge and skills within entrepreneurship education (Bell and Bell, 2020). For the development of entrepreneurial skills, it has been found that experiential learning, through authentic entrepreneurial experiences are most effective (Bell, 2015; Macht and Ball, 2016).

However, in the Iranian entrepreneurship education context it has been highlighted that experiential education can be limited and would benefit from being extended (Ahadi and Kasraie, 2020). To facilitate the inclusion and development of more experiential entrepreneurship education, adjustments to the rules and structures within Iranian higher education may be required (Farsi et al., 2014). To achieve this, educational policy makers will need to support the development of practical and experiential entrepreneurial curricular, which can increase the skills and practical capabilities of nascent entrepreneurs (Ahadi and Kasraie, 2020). However, it has been highlighted that it is important to consider context and culture, as it can be a challenge for students to adapt to experiential approaches (Bell, 2020a). Plus, in cultures where society widely accepts the authority and wisdom of teachers, student centered experiential approaches might be less effective (Ismail et al., 2018). Therefore, the educational experience should be tailored to the Iranian context.

The third hypothesis is based on the effect of entrepreneurial mindset on entrepreneurial alertness. The results suggest a positive and significant effect of entrepreneurial mindset on entrepreneurial alertness. As far as we know, this study is the first to focus on the effect of entrepreneurial mindset on entrepreneurial alertness. This study might be the first to explicitly link these two concepts together, reducing the dearth in understanding as to what entrepreneurial mindset leads to (Daspit et al., 2021); but this supports the proposition put forward by Pirhadi et al. (2021) that entrepreneurial skills and character can help to develop the ability to assess desirability and feasibility of entrepreneurial opportunities.

The fourth hypothesis is based on the indirect effect of entrepreneurship education on entrepreneurial alertness with the mediating role of entrepreneurial mindset, which was also confirmed. This finding presents a novel contribution to the literature as the linkage between these concepts is currently underexplored. Previous research has employed entrepreneurial mindset almost exclusively as a dependent variable (Daspit et al., 2021), so understanding its 
Saadat, S., Aliakbari, A., Alizadeh Majd, A. \& Bell, R. (2021) The effect of entrepreneurship education on graduate students' entrepreneurial alertness and the mediating role of entrepreneurial mindset, Education + Training. doi: 10.1108/ET-06-2021-0231

mediating role in supporting the development of entrepreneurial alertness, a stage where potential entrepreneurs can identify actionable opportunities, provides new insights as to its value in entrepreneurship education. This has highlighted that the development of entrepreneurial mindset through entrepreneurship education is an important step to further the development of entrepreneurial alertness, which in turn is critical to spotting and identifying entrepreneurial opportunities. This may help to encourage the development of entrepreneurship and SMEs, which have not always been supported by effective entrepreneurship education in Iran (Ahadi and Karaie, 2020).

Based on the findings of this study, entrepreneurship education positively affects the entrepreneurial mindset. This means that entrepreneurship education will positively change the students' way of thinking or enhance the ability to utilize opportunities under uncertain conditions (Cui et al., 2021). Consequently, improving entrepreneurial mindset through entrepreneurship education will boost entrepreneurial alertness, that is the ability to assemble random pieces of scattered information and combine them to analyze and achieve an entrepreneurial opportunity (Tang et al., 2012). Moreover, entrepreneurship education directly has a positive effect on entrepreneurial alertness. Indeed, a high degree of entrepreneurial alertness leads to a high potential of opportunities and unseen situations discovery (Kirzner, 1999). Research argues that equipping students with entrepreneurial alertness and entrepreneurial mindset requires learning through entrepreneurship education (Schmidt and Ford, 2003; Solesvik et al., 2013).

In terms of the practical implications of the results, the findings highlight the value of entrepreneurship education not only being focused on idea development and entrepreneurial alertness, but also ensuring that entrepreneurial mindset is supported in the entrepreneurship education process, as entrepreneurial mindset has a mediating role in the relationship between entrepreneurship education and entrepreneurial alertness. There is the potential for entrepreneurship education to become overly focused on entrepreneurial alertness and supporting students to develop entrepreneurial ideas, but the development of entrepreneurial mindset is also important through entrepreneurship education. Previous literature has proposed providing students with scaffolded experiences by allowing them to identify areas where they can add value to external stakeholders and then enacting the creation of this value (Bell, 2020b; Lackéus, 2020). Such experiential approaches to entrepreneurship education can allow students to develop their entrepreneurial alertness and entrepreneurial mindset by allowing them to 
Saadat, S., Aliakbari, A., Alizadeh Majd, A. \& Bell, R. (2021) The effect of entrepreneurship education on graduate students' entrepreneurial alertness and the mediating role of entrepreneurial mindset, Education + Training. doi: 10.1108/ET-06-2021-0231

create meaning from their own experiences and environment. These experiences can be particularly relevant to them, allowing linkage between their context, interests, and skill sets.

\section{Conclusions}

This research examined the influences of entrepreneurship education on entrepreneurial alertness and the mediating role of entrepreneurial mindset. Our findings show a direct and indirect effect (via the mediating variable of entrepreneurial mindset) of entrepreneurship education on entrepreneurial alertness. This provides an understanding of the process as to how entrepreneurship education can lead to the development of entrepreneurial alertness. This meets calls to further our understanding of how entrepreneurship education influences entrepreneurial mindset (Nabi et al. 2017; Yatu et al. 2018). In addition, exploring the mediating influence of entrepreneurial mindset helps to further the understanding of its impact in the pedagogical and educational process (Daspit et al., 2021).

The findings that entrepreneurship education positively affects students' entrepreneurial alertness and mindset, highlights the importance for higher education institutions to provide adequate resources for such programs. The research suggests that students with the right entrepreneurial knowledge and skills are more alert to, and ready, to exploit opportunities even under uncertain conditions. In Iran's economic, social, and cultural development document of the country (fourth, fifth, and sixth documents), the role of entrepreneurship education is highly emphasized. Although, in practice, the education system in Iran has not adequately invested in entrepreneurship educational infrastructures. We suggest that policymakers should provide the conditions to put entrepreneurship education into practice more when moving forward.

The research highlights the importance of blending both entrepreneurial knowledge and skills in entrepreneurship education to build entrepreneurial mindset and entrepreneurial alertness. This needs to be delivered in a manner which is suitable for the given context but can develop students' ability to have an entrepreneurial mindset which can support both their employment and potential future entrepreneurial endeavors. Entrepreneurship education which builds both knowledge and practical entrepreneurial skills is important to prepare nascent entrepreneurs through the development of an entrepreneurial mindset and support for opportunity identification. The recognition of this is important for Iranian policy makers, to ensure that 
Saadat, S., Aliakbari, A., Alizadeh Majd, A. \& Bell, R. (2021) The effect of entrepreneurship education on graduate students' entrepreneurial alertness and the mediating role of entrepreneurial mindset, Education + Training. doi: 10.1108/ET-06-2021-0231

education programs take advantage of the benefits of experiential education, alongside a focus on more traditional teaching approaches (Ahadi and Kasraie, 2020).

This research moved beyond considering entrepreneurial mindset as solely an outcome of entrepreneurship education, to how it can support the development of entrepreneurial alertness. The finding that entrepreneurial mindset can mediate the influence of entrepreneurship education on entrepreneurial alertness is important as it highlights the importance of developing students' entrepreneurial mindset, rather than entrepreneurship education being only focused on entrepreneurial opportunities and entrepreneurial alertness. The process of developing entrepreneurial mindset is context and individual specific and therefore it is important for educators to allow students and cohorts to engage with their own skill sets and environments, to help them enhance their entrepreneurial alertness.

This study was conducted in the context of Iran, which is relatively unique given the economic situation and the imposition of sanctions, both of which might influence and impact nascent entrepreneurs. However, the results could be used to inform entrepreneurship education in contexts where entrepreneurship education is at a relatively early stage and is still developing. The results might also be of value to culturally similar countries. Where technology and resources are not so freely available it is likely to be more challenging to identify and take advantage of entrepreneurial opportunities. The importance of entrepreneurial mindset to support entrepreneurial alertness and the identification of entrepreneurial opportunities could be a particularly valuable asset in contexts where resources and technology are hard to acquire.

As with all research, this research has some limitations. The first limitation is that this research has only considered the relationship between entrepreneurial mindset and entrepreneurial alertness through entrepreneurship education. Accordingly, the study's variables could be examined with other crucial factors such as entrepreneurial intention, entrepreneurial adaptability, entrepreneurial self-efficacy, and entrepreneurial attitude. Other factors might influence the relationship between entrepreneurship education, entrepreneurial mindset and entrepreneurial alertness, but this research has laid the groundwork for future research to study the influence of other variables further. The second limitation is whether students having work experience, or not, may affect the results; we suggest future researchers could choose specific groups of students, with and without work experience, to compare the findings. Graduate students were selected as the sample for this research, as they might be the most likely to have the resources, capital, and networks to start a new venture. However, the impact of 
Saadat, S., Aliakbari, A., Alizadeh Majd, A. \& Bell, R. (2021) The effect of entrepreneurship education on graduate students' entrepreneurial alertness and the mediating role of entrepreneurial mindset, Education + Training. doi: 10.1108/ET-06-2021-0231

entrepreneurship education and its impact on entrepreneurial mindset and entrepreneurial alertness could be different on different cohorts, therefore further research could investigate this further. The final limitation is that entrepreneurship education may be affected by the differences between short-term entrepreneurship training courses (non-academic) and university entrepreneurship courses (academic). Future researchers could explore the quality of education in academic and non-academic courses. The measures used within this research to assess entrepreneurship education were focused on entrepreneurship knowledge and skill development, in line with what previous research had suggested were important elements of effective entrepreneurship education (e.g., Bell and Bell, 2020). However, further research could explore what elements of entrepreneurship education specifically led to the development of entrepreneurial mindset and entrepreneurial alertness, to further our understanding of the value of different entrepreneurship education approaches. 
Saadat, S., Aliakbari, A., Alizadeh Majd, A. \& Bell, R. (2021) The effect of entrepreneurship education on graduate students' entrepreneurial alertness and the mediating role of entrepreneurial mindset, Education + Training. doi: 10.1108/ET-06-2021-0231

\section{References}

Abreu, M., Demirel, P., Grinevich, V. and Karataş-Özkan, M. (2016), "Entrepreneurial practices in research-intensive and teaching-led universities", Small Business Economics, Vol. 47 No. 3, pp.695-717.

Afrianty, T. (2020), "Questionnaire for entrepreneurship education, entrepreneurial selfefficacy and entrepreneurial intentions", Mendeley Data. doi: 10.17632/4wyfmbxz4d.2

Ahadi, S. and Kasraie, S. (2020), "Contextual factors of entrepreneurship intention in manufacturing SMEs: the case study of Iran", Journal of Small Business and Enterprise Development, Vol. 24 No. 4, pp.633-657

Ardichvili, A. and Cardozo, R.N. (2000), "A model of the entrepreneurial opportunity recognition process", Journal of Enterprising Culture, Vol. 8 No. 2, pp.103-119.

Ardichvili, A., Cardozo, R. and Ray, S. (2003), "A theory of entrepreneurial opportunity identification and development”, Journal of Business Venturing, Vol. 18 No. 1, pp.105-123.

Avramenko, A. (2012), "Enhancing students' employability through business simulation", Education + Training, Vol. 54 No. 5, pp. 355-367.

Bell, R. (2015), "Developing the next generation of entrepreneurs: Giving students the opportunity to gain experience and thrive", The International Journal of Management Education, Vol. 13 No. 1, pp. 37-47.

Bell, R. (2016), "Unpacking the link between entrepreneurialism and employability: An assessment of the relationship between entrepreneurial attitudes and likelihood of graduate employment in a professional field", Education + Training, Vol. 58 No. 1, pp. 2-17.

Bell, R. (2020a), “Adapting to constructivist approaches to entrepreneurship education in the Chinese classroom", Studies in Higher Education, Vol. 45 No. 8, pp. 1694-1710.

Bell, R. (2020b), "Developing entrepreneurial behaviours in the Chinese classroom through value creation pedagogy", Innovations in Education and Teaching International. doi 10.1080/14703297.2020.1793800.

Bell, R. and Bell, H. (2016), “An enterprise opportunity for entrepreneurial students: Student enterprise development and experience assessed through the student voice", Education + Training, Vol. 58 No. 7/8, pp. 751-765. 
Saadat, S., Aliakbari, A., Alizadeh Majd, A. \& Bell, R. (2021) The effect of entrepreneurship education on graduate students' entrepreneurial alertness and the mediating role of entrepreneurial mindset, Education + Training. doi: 10.1108/ET-06-2021-0231

Bell, R. and Bell, H. (2020), “Applying educational theory to develop a framework to support the delivery of experiential entrepreneurship education", Journal of Small Business and Enterprise Development, Vol. 27 No. 6, pp. 987-1004.

Bhalla, G. and Lin, L. (1987), "Cross-cultural marketing research: a discussion of equivalence issues and measurement strategies", Psychology and Marketing, Vol. 4, pp. 185-216.

Bland, J.M. and Altman, D.G. (1997), "Statistics notes: Cronbach's Alpha”, British Medical Journal, Vol. 314, p. 572.

Bliemel, M.J. (2013), “Getting entrepreneurship education out of the classroom and into students' heads", Entrepreneurship Research Journal, Vol. 4 No. 2, pp. 237-260.

Bueckmann-Diegoli, R., Sánchez, M. del M.G. de los S. and Gutiérrez, H.S.M. (2020), “The development of entrepreneurial alertness in undergraduate students", Education + Training. doi: 10.1080/00472778.2021.1907584

Chang, J., Benamraoui, A. and Rieple, A. (2014), "Learning-by-doing as an approach to teaching social entrepreneurship", Innovations in Education and Teaching International, Vol. 51 No. 5, pp. 459-471.

Cool, K., Dierickx, I. and Jemison, D. (1989), "Business strategy, market structure and riskreturn relationships: A structural approach”, Strategic Management Journal, Vol. 10 No. 6, pp.507-522.

Corbett, A.C. (2007), "Learning asymmetries and the discovery of entrepreneurial opportunities", Journal of Business Venturing, Vol. 22 No. 1, pp.97-118.

Covin, J.G. and Slevin, D.P. (2017), “The entrepreneurial imperatives of strategic leadership", Hitt, M., Ireland, D., Camp, M, and Sexton, D. (Ed.), Strategic entrepreneurship: Creating a new mindset, Wiley, Hoboken, NJ, pp.307-327.

Cui, J., Sun, J. and Bell, R. (2021), "The impact of entrepreneurship education on the entrepreneurial mindset of college students in China: The mediating role of inspiration and the role of educational attributes", The International Journal of Management Education, Vol. 19 No. 1, 100296.

Daneshjoovash, S.K. and Hosseini, M.H. (2019), "Evaluating impact of entrepreneurship education programs", Education + Training, Vol. 61 No. 7/8, pp. 781-796. 
Saadat, S., Aliakbari, A., Alizadeh Majd, A. \& Bell, R. (2021) The effect of entrepreneurship education on graduate students' entrepreneurial alertness and the mediating role of entrepreneurial mindset, Education + Training. doi: 10.1108/ET-06-2021-0231

Daspit, J.J., Fox, C.J. and Findley, S.K. (2021), "Entrepreneurial mindset: An integrated definition, a review of current insights, and directions for future research", Journal of Small Business Management. doi: 10.1080/00472778.2021.1907583

Dehghanpour Farashah, A. (2013), "The process of impact of entrepreneurship education and training on entrepreneurship perception and intention: Study of educational system of Iran", Education + Training, Vol. 55 No. 8/9, pp. 868-885.

Dutta, D.K., Li, J. and Merenda, M. (2011), "Fostering entrepreneurship: Impact of specialization and diversity in education", International Entrepreneurship and Management Journal, Vol. 7 No. 2, pp.163-179.

Farsi, J.Y., Modarresi, M., Motavaseli, M. and Salamzadeh, A. (2014), "Institutional factors affecting academic entrepreneurship: The case of University of Tehran", Economic Analysis, Vol. 47, pp. 139-159.

Fornell, C., and Larcker, D.F. (1981), "Evaluating structural equation models with unobservable variables and measurement error", Journal of Marketing Research, Vol. 18 No. 1, pp. 39-50.

Fuduric, N. (2008), Individuals \& Opportunities: A resource-based and institutional view of entrepreneurship. PhD Thesis, Aalborg University, Denmark.

Gaglio, C.M. and Katz, J.A. (2001), "The psychological basis of opportunity identification: Entrepreneurial alertness”, Small Business Economics, Vol. 16 No. 2, pp.95-111.

Global Entrepreneurship Monitor (GEM) (2020) Iran Report - 2020/2021. Available from https://www.gemconsortium.org/economy-profiles/iran-2 [Accessed 21st June 2021].

Gibb, A. (2007), "Creating the entrepreneurial university: Do we need a wholly different model of entrepreneurship", Alain Fayolle (Ed.), Handbook of research in entrepreneurship education, Edward Elgar Publishing, Cheltenham, pp.67-103.

Henseler, J., Ringle, C.M. and Sinkovics, R.R. (2009), "The use of partial least squares path modeling in international marketing", Sinkovics, R.R. and Ghauri, P.N. (Ed.) New Challenges to International Marketing (Advances in International Marketing, Vol. 20), Emerald Group Publishing Limited, Bingley, pp. 277-319.

Helfat, C.E. and Peteraf, M.A. (2015), "Managerial cognitive capabilities and the microfoundations of dynamic capabilities", Strategic Management Journal, Vol. 36 No. 6, pp.831-850. 
Saadat, S., Aliakbari, A., Alizadeh Majd, A. \& Bell, R. (2021) The effect of entrepreneurship education on graduate students' entrepreneurial alertness and the mediating role of entrepreneurial mindset, Education + Training. doi: 10.1108/ET-06-2021-0231

Hodgetts, R.M. and Kuratko, D.F. (1989,) Effective small business management, Harcourt Brace Jovanovich, Orlando, FL.

Hulland, J. (1999), "Use of partial least squares (PLS) in strategic management research: A review of four recent studies", Strategic Management Journal, Vol. 20 No. 2, pp. 195-204.

Ismail, A.B.T., Sawang, S. and Zolin, R. (2018), "Entrepreneurship education pedagogy: teacher-student-centred paradox", Education + Training, Vol. 60 No. 2, pp. 168-184.

Karlsson, T. and Moberg, K. (2013) "Improving perceived entrepreneurial abilities through education: Exploratory testing of an entrepreneurial self-efficacy scale in a pre-post setting”, The International Journal of Management Education, Vol. 11, No. 1, pp. 1-11.

Kelley, D.J., Singer, S. and Herrington, M. (2012), The global entrepreneurship monitor. 2011 Global Report, GEM 2011.

Kirzner, I. (2008), “The alert and creative entrepreneur: A clarification”, IFN Working Paper No. 760, Stockholm SE: Research Institute of Industrial Economics.

Kirzner, I.M. (1973), Entrepreneurship and competition, University of Chicago Press, Chicago, IL.

Kirzner, I.M. (1979) Perception, opportunity, and profit: Studies in the theory of entrepreneurship, University of Chicago Press, Chicago, IL.

Kirzner, I.M. (2009), “The alert and creative entrepreneur: A clarification”, Small Business Economics, Vol. 32 No. 2, pp.145-152.

Kirzner, I.M. (1986), Subjectivism, intelligibility and economic understanding: essays in honor of Ludwig M. Lachmann on his eightieth birthday, New York University Press, New York, NY.

Kirzner, I.M. (1997), "Entrepreneurial discovery and the competitive market process: An Austrian approach”, Journal of Economic Literature, Vol. 35 No. 1, pp.60-85.

Kirzner, I.M. (1999), "Creativity and/or alertness: A reconsideration of the Schumpeterian entrepreneur", The Review of Austrian Economics, Vol. 11 No. 1-2, pp.5-17.

Karimi, S., Chizari, M., Biemans, H.J.A. and Mulder, M. (2010), "Entrepreneurship Education in Iranian Higher Education: The Current State and Challenges", European Journal of Scientific Research, Vol. 48 No. 1, pp. 35-50. 
Saadat, S., Aliakbari, A., Alizadeh Majd, A. \& Bell, R. (2021) The effect of entrepreneurship education on graduate students' entrepreneurial alertness and the mediating role of entrepreneurial mindset, Education + Training. doi: 10.1108/ET-06-2021-0231

Kozlinska, I. (2012), "Fundamental view of the outcomes of entrepreneurship education", The University of Tartu Faculty of Economics and Business Administration Working Paper, No. 90.

Krauss, S.I., Frese, M., Friedrich, C. and Unger, J.M. (2005), "Entrepreneurial orientation: A psychological model of success among southern African small business owners", European Journal of Work and Organizational Psychology, Vol. 14 No. 3, pp.315-344.

Krueger, N. (2015) Entrepreneurial education in practice-part 1 the entrepreneurial mindset. OCDE, Paris.

Kuratko, D.F. (2005), “The Emergence of Entrepreneurship Education: Development, Trends, and Challenges", Entrepreneurship Theory \& Practice, Vol. 29 No. 5, pp. 577-597.

Lackéus, M. (2020), “Comparing the impact of three different experiential approaches to entrepreneurship in education", International Journal of Entrepreneurial Behavior \& Research, Vol. 26 No. 5, pp. 937-971.

Lee, K., Kim, Y. and Koh, D. (2016), “Organizational learning, top management team's entrepreneurial alertness, and corporate entrepreneurship in high-tech firms", Asian Journal of Technology Innovation, Vol. 24 No. 3, pp.338-360.

Lumpkin, G.T. and Lichtenstein, B.B. (2005), 'The role of organizational learning in the opportunity-recognition process", Entrepreneurship Theory and Practice, Vol. 29 No. 4, pp. 451-472.

Mathisen, J.E. and Arnulf, J.K. (2014), "Entrepreneurial mindsets: Theoretical foundations and empirical properties of a mindset scale", International Journal of Management and Business, Vol. 5 No. 1, pp.81-97

McGrath, R.G. and MacMillan, I.C. (2000), The entrepreneurial mindset: Strategies for continuously creating opportunity in an age of uncertainty, Harvard Business Press, Boston, MA.

McMullen, J.S. and Kier, A.S. (2016), “Trapped by the entrepreneurial mindset: Opportunity seeking and escalation of commitment in the Mount Everest disaster", Journal of Business Venturing, Vol. 31 No. 6, pp. 663-686.

Naeiji, M.J. and Ebrahimi, E. (2017), "The Effect of Entrepreneurship Training on Entrepreneurial Mindset: Mediating Role of Creativity and Entrepreneurial Alertness. (Organizations of MOD)", Innovation Management Journal, Vol. 6 No. 1, pp. 73-100. 
Saadat, S., Aliakbari, A., Alizadeh Majd, A. \& Bell, R. (2021) The effect of entrepreneurship education on graduate students' entrepreneurial alertness and the mediating role of entrepreneurial mindset, Education + Training. doi: 10.1108/ET-06-2021-0231

Macht, S.A. and Ball, S. (2016), “Authentic Alignment' - a new framework of entrepreneurship education", Education + Training, Vol. 58 No. 9, pp. 926-944.

Minniti, M. (2004), "Entrepreneurial alertness and asymmetric information in a spin-glass model”, Journal of Business Venturing, Vol. 19 No. 5, pp.637-658.

Muñoz, C.C.A., Mosey, S. and Binks, M. (2011), "Developing opportunity-identification capabilities in the classroom: Visual evidence for changing mental frames", Academy of Management Learning \& Education, Vol. 10 No. 2, pp. 277-295.

Muñoz, C.A., Guerra, M.E. and Mosey, S. (2020), “The potential impact of entrepreneurship education on doctoral students within the non-commercial research environment in Chile", Studies in Higher Education, Vol. 45 No. 3, pp.492-510.

Nabi, G., Liñán, F., Fayolle, A., Krueger, N. and Walmsley, A. (2017), “The Impact of Entrepreneurship Education in Higher Education: A Systematic Review and Research Agenda", Academy of Management Learning \& Education, Vol. 16 No. 2, pp. 277-299.

Neneh, B.N. (2019), "From entrepreneurial alertness to entrepreneurial behavior: The role of trait competitiveness and proactive personality", Personality and Individual Differences, Vol. 138, pp. 273-279.

Netemeyer, R., Bearden, W. and Sharma, S. (2003), Scaling Procedures: Issues and Applications, Sage, London.

Nowiński, W., Haddoud, M.Y., Lančarič, D., Egerová, D. and Czeglédi, C. (2019), “The impact of entrepreneurship education, entrepreneurial self-efficacy and gender on entrepreneurial intentions of university students in the Visegrad countries", Studies in Higher Education, Vol. 44 No. 2, pp. 361-379

Nyadu-Addo, R. and Mensah, M.S.B. (2018), "Entrepreneurship education in Ghana - the case of the KNUST entrepreneurship clinic", Journal of Small Business and Enterprise Development, Vol. 25 No. 4, pp. 573-590.

O’Brien, E., M. Cooney, T. and Blenker, P. (2019), "Expanding university entrepreneurial ecosystems to under-represented communities", Journal of Entrepreneurship and Public Policy, Vol. 8 No. 3, pp. 384-407.

O'Connor, A. (2013), “A conceptual framework for entrepreneurship education policy: Meeting government and economic purposes”, Journal of Business Venturing, Vol. 28 No. 4, pp.546-563. 
Saadat, S., Aliakbari, A., Alizadeh Majd, A. \& Bell, R. (2021) The effect of entrepreneurship education on graduate students' entrepreneurial alertness and the mediating role of entrepreneurial mindset, Education + Training. doi: 10.1108/ET-06-2021-0231

Olutuase, S.O., Brijlal, P., Yan, B. and Ologundudu, E. (2018), "Entrepreneurial orientation and intention: Impact of entrepreneurial ecosystem factors", Journal of Entrepreneurship Education, Vol. 21 No. 1, pp. 1-14.

Outsios, G. and Kittler, M. (2018), "The mindset of UK environmental entrepreneurs: A habitus perspective”, International Small Business Journal, Vol. 36 No. 3, pp. 285-306.

Pirhadi, H., Soleimanof, S. and Feyzbakhsh, A. (2021), "Unpacking entrepreneurial alertness: How character matters for entrepreneurial thinking”, Journal of Small Business Management. doi: 10.1080/00472778.2021.1907584

Schmidt, A.M. and Ford, J.K. (2003), "Learning within a learner control training environment: The interactive effects of goal orientation and metacognitive instruction on learning outcomes", Personnel psychology, Vol. 56 No. 2, pp.405-429.

Shepherd, D.A., Patzelt, H. and Haynie, J.M. (2010), "Entrepreneurial spirals: Deviationamplifying loops of an entrepreneurial mindset and organizational culture", Entrepreneurship Theory and Practice, Vol. 34 No. 1, pp.59-82.

Solomon, G. (2008), "Entrepreneurship education in the United States", in Potter, J. (Ed.), Entrepreneurship and Higher Education, OECD and LEED, Paris, pp. 95-118.

Singer, S., Amoros, J. and Arreola, D. (2015), Global Entrepreneurship Monitor 2014 Global Report, Global Entrepreneurship Research Association, London.

Sirelkhatim, F. and Gangi, Y. (2015), "Entrepreneurship education: A systematic literature review of curricula contents and teaching methods", Cogent Business \& Management, Vol. 2 No. 1, pp. 1-11.

Solesvik, M.Z., Westhead, P., Matlay, H. and Parsyak, V.N. (2013), "Entrepreneurial assets and mindsets: Benefit from university entrepreneurship education investment", Education + Training, Vol. 55 No. 8-9, pp. 748-762.

Tang, J., Kacmar, K.M.M. and Busenitz, L. (2012), "Entrepreneurial alertness in the pursuit of new opportunities", Journal of Business Venturing, Vol. 27 No. 1, pp.77-94.

Yatu, L., Bell, R. and Loon, M. (2018), "Entrepreneurship education research in Nigeria: current foci and future research agendas", African Journal of Economic and Management Studies, Vol. 9 No. 2, pp. 165-177. 
Saadat, S., Aliakbari, A., Alizadeh Majd, A. \& Bell, R. (2021) The effect of entrepreneurship education on graduate students' entrepreneurial alertness and the mediating role of entrepreneurial mindset, Education + Training. doi: 10.1108/ET-06-2021-0231

Appendix 1 Eliminated Items Factor loading $<0.4$

\section{Entrepreneurship Education}

I understand the theories taught in the entrepreneurship course I learnt from practicing entrepreneurs during the entrepreneurship course

I learnt from case studies of successful entrepreneurs during the entrepreneurship course

\section{Entrepreneurial Alertness}

I have frequent interactions with others to acquire new information

I always keep an eye out for new business ideas when looking for information

I read news, magazines, or trade publications regularly to acquire new information

I have a gut feeling for potential opportunities

I can distinguish between profitable opportunities and not-so-profitable opportunities

I have an extraordinary ability to smell profitable opportunities

When facing multiple opportunities, I am able to select the good ones

\section{Entrepreneurial Mindset}

I can rarely see connections between previously unconnected domains of information I can distinguish between profitable opportunities and non-profitable opportunities When facing multiple opportunities, I find it difficult to select the good ones I like to take chances, although I may fail

I like waiting until things has been tested before I try it

To earn greater rewards, I am willing to take higher risks

I only like to implement a plan if its outcome is very certain

I seek new experiences even if their outcomes may be risky

If I am uncertain about the responsibilities involved in a task, I get very anxious

It really disturbs me when I am unable to follow another person's train of thought

I can tolerate ambiguous conditions and unpredictable results

Before any important task, I must know how long it will take

A good task is one in which what is to be done and how it is to be done are always clear In uncertain times, I would expect the best

If something can go wrong with me, it will

I hardly ever expect things to go my way

I rarely count on good things happening to me

Overall, I expect more good things to happen to me than bad 